\title{
Plant Exudates and Enzymes Cocktails for Semi-deligni-holocellulolysis
}

\author{
Justine O. Angadam, Rachel K. Kanda, Boredi S. Chidi, and Seteno Karabo O. Ntwampe
}

\begin{abstract}
Plants and insects have been interacting since the creation of the world. The common scenario is of insects feeding on plants. But for over 100 years now, the opposite situation has been taking place whereby plants feed on insects. This is experienced in carnivorous plants with the help of their special features (pitcher traps). Plants exudates and enzymes cocktails contain a great deal of useful constituents which are both useful to plants and human beings too. These constituents of plants can be collected and purify in the laboratories and industries using cost effectives methods such as fractionation techniques. Production of these plants discharges is very important as it serves as a defense mechanism to plants, as medication to mankind, food preservatives, flavor components in food and drinks for little or no cost. The purpose of this review is to make use of readily naturally available discharges from plants for the process of semi-deligni-holocellulolysis. A brief summary of plant exudates and fluids, its components and purification are highlighted.
\end{abstract}

Keywords - Plant defense, plants exudates, carnivorous plants, pitcher traps, Nepenthes spp.

\section{INTRODUCTION}

Plants has been used from the beginning of mankind as food, as a source of beverages as well as medicinal purposes. In order to benefits from all the above mentioned benefits, it is necessary to know the chemical constituents present in the plant. This is very essential because microbial toxins can sporadically enter the food chain (Puri and Hall 1998) Plants like human beings faced and respond to environmental challenges which include soil conditions and the availability of microorganisms. They respond by excretion naturally occurring polysaccharide gums known as exudates which are one of the greatest copious raw materials.

These exudates are produced from several parts of plants (example include; plant cell walls, seeds, tuber/roots, etc.). In food industries, these exudates are used as additives. The composition of plant exudates comprises of sugars, amino acids, peptides, enzymes, vitamins, organic acids, nucleotides, fungal stimulators, inhibitors and attractants etc. A suggestion to deliberate on the subject plants exudates in a broad manner, with no emphasis on a specific collection of compounds, be it stimulatory or inhibitory. Roots hold plants firmly in the soil, it

Manuscript received October 14, 2019. This work was supported in part by the CPUT VC's prestigious award and the National Research Foundation of South Africa.

All authors are with the Bioresource Engineering Research Group (BioERG), Department of Biotechnology, Cape Peninsula University of Technology, P.O. Box 652, Cape Town 8000, South Africa; is the main source of water and nutrient uptake forces from the roots to the leaves, and also defend the plant efficiently against detrimental microorganisms (Mirhosseini and Amid 2012);

Plants secrete an extensive collection of high and low-molecular-weight defense compounds in deficiency of pathogen stimulant. The name given to low-molecular-weight antimicrobial chemicals that are present in the plant before biotic stress are known as phytoanticipins. But, the low-molecular-weight antimicrobial complexes that are not measureable in healthy plants are known as phytoalexins. The plant exudates that fit to the chemical class of phenolics and terpenoids have tough external antibacterial and antifungal abilities.

\section{COMPOSITION OF PLANT EXUdATES: OVERVIEW}

Research has also shown that, molecules such as amino acids can function as stimulator for a certain group of microbes, nonetheless as a suppressor for other soil bacteria. Phenylpropanoids are abundant plant phenolics that are found as a result of roots exudates which are used for defense, flavonoids characterize one of the major classes of phenylpropanoid and constitute a large proportion of plant root exudates (Wen, VanEtten et al. 2007, Baetz and Martinoia 2014). The prevalent class of chemicals that plant used as defence mechanism above soil surface and under the ground are terpenoids, they also form part of the root exudates. Recently, volatile organic compounds were shown to be released from roots that serve as a defense mechanism (Wen, Van Etten et al. 2007).

\section{A. Usefulness of Plants Exudates}

The composition of plant exudates if known, will be useful to a wide range of people including; food scientists, nutritionists, pharmacists, chemical ecologists, Pharmacognosists, biologists and not forgetting phytochemists as its include phenolics, alkaloids and plant glycoside to essential oils and triterpenoids (Puri and Hall 1998). The components of plants are many and are used in different areas of life. This research is focused specifically on the bioactive components of plants exudates underground and above earth surface.

\section{B. Bioactive Constituents of Plant Exudates}

There exit some bioactive constituents of plant exudates which include; amylase, invertase, phosphatase, protease, polygalacturonase, amino acids, organic acids, reducing sugars, phenolics, flavonoids etc. Plants exudates can be used for medicinal purposes such as treatment for bone fractures, arthritis, inflammation, obesity, cardiovascular disease, and 
lipid disorders. For example, plant exudate from Pycanthus angolenses has been reported to be effective in the treatment of cancer, leprosy and diabetes, used to waterproof boats, ships and other structures (Pichersky and Raguso 2018). Some plants exudates are of commercially importance e.g. rubber. Several terpenoids in herbs for example lemon grass and some in spices, contain unstable terpenoids which serves as the main flavor components in food, alcoholic drinks, and wine in specifically, this is due mostly because of the present of terpenes. They are also used as food preservative because of their microbicidal and insecticidal properties.

\section{Co-factors and Reasons for the Production of Exudates}

These plant exudates are influence by some growth factors such as p-Amino benzoic acid, auxins, biotin, choline, inositol, n-methyl nicotinic acid, niacin, pantothenate, pyridoxine, thiamine etc. (Flores and Ricalde 1996, Okwu and Nnamdi 2008, Pichersky and Raguso 2018). Plants produce exudates for several reasons some of which are; defense against herbivores and pathogens, evolution of new genes. Fig 1 illustrates some exudates from different plant parts.
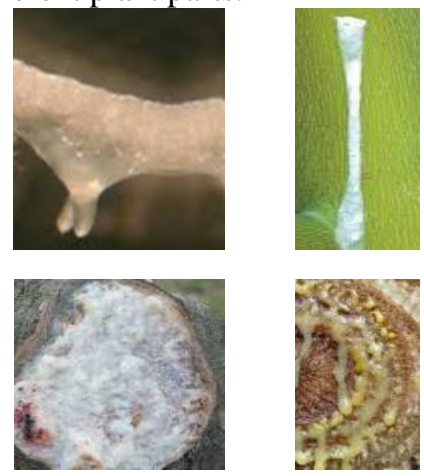

Fig. 1. Plant stems and root releasing exudates.

\section{BIOACTIVE CONSTITUENTS OF PLANT FLUID OF THE GENUS NEPENTHES}

Similarly, it has been researched that, plant cocktails from carnivorous pitcher plants of the genus Nepenthes, also constitute a number of bioactive substances as a results of caught insects which are digested in the pitcher fluid with the help of their special features of the pitcher traps. These bioactive substances are not limited to; $\beta$-glucosidases, xylanases and carboxylesterases protease, ribonuclease, nuclease, phosphatase hydrolase, esterases, ribonucleases, and amylases. Though pitcher fluid has been known for many decades, our awareness of the pitcher fluid constitution is quiet narrow (Mithöfer 2011, Angadam, Dlangamandla et al. 2019, Dlangamandla, Ntwampe et al. 2019). These Nepenthes species are insectivorous by nature and they are characterised by their specialized danger traps, thus the name pitcher, which traps preys and decay organisms that are indestructible and filled the cups with protein (Lee, Zhang et al. 2016). Furthermore, most pitcher plant species are known for producing acidic fluid, with a $\mathrm{pH}$ ranges between 1.5 to 6 depending on the species (Dlangamandla, Ntwampe et al. 2019). However, research has proven the bioactive constituents of the acidic fluids nature of pitcher plants extract produced by carnivorous plants, a lot still need to be done as concerns the usage of this extract (Takeuchi,
Chaffron et al. 2015). Fig 2 illustrates different traps which produces digestive extracts. Some of these enzymes found in both plants exudates and in Nepenthes species, play a big role in the delignification and also the breaking down of holocellulose (Gallie and Chang 1997, Schulze, Sanggaard et al. 2012, Dlangamandla, Ntwampe et al. 2019).

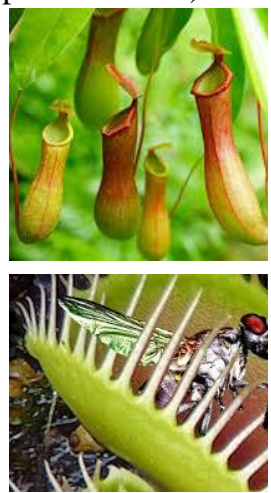

Fig. 2. Prey entrapment plant parts for different Nepenthes plants

\section{MethodS AND MATERIALS}

\section{A. Quantifying Biocatalytic Activity of Enzymes in Nepenthes Species Digestive Fluids}

Biodegradation activity of a few enzymes namely; carboxylesterases, $\beta$-glucosidases and xylanases based on their ability to decompose the agro-waste components forming by-products was conducted. It was earlier acknowledged as being an indispensable cellulose biodegrading components aiding the transformation of cellobiose, which is a reducing sugar, to glucose, additionally, they are known by their abilities to biodegrade hemicellulose (Chan, Hong et al. 2016, Manavalan, Liu et al. 2017) and again, they hydrolyses the bonds between holocellulose sugars and lignin.

All test concoctions were mixed in tubes, thereafter; it was transfer in to glass cuvettes in order to read absorbance in a kinetic mode. All reaction was performed at $25^{\circ} \mathrm{C}$. Quantification of $\beta$-glucosidases activity in Nepenthes spices digestive fluid was measured using p-nitrophenyl- $\beta$-D-glucopyranoside (pNPG) as a substrate. The reaction mixture is composed of $600 \mu \mathrm{L} 50 \mathrm{mM}$ sodium acetate $(\mathrm{pH} 6), 0.35 \mathrm{mM}$ pNPG, and enzyme $(100 \mu \mathrm{L})$. The reaction was carried out at $420 \mathrm{~nm}$, with extinction coefficient of $18100 \mathrm{M}^{-1} . \mathrm{cm}^{-1}$ to monitor the product formed (Dlangamandla, Ntwampe et al. 2019).

Xylanase activity was also quantified using endo-xylan as a substrate. The reaction mix was made up of $100 \mathrm{mM}$ Mcllvaine's citrate phosphate buffer ( $\mathrm{pH}$ 5), wave length of $586 \mathrm{~nm}$ using an extinction coefficient of $135 \mathrm{M}-1 . \mathrm{cm}-1$ to quantify the product formed, i.e. xylose.(Zabed, Sahu et al. 2016).

Equally, carboxylesterases activity was quantified using $\rho$-nitrophenyl acetate ( $\rho \mathrm{NPA})$ as substrate (Manavalan, Liu et al. 2017, Dlangamandla, Ntwampe et al. 2019). The assays were performed using a Nepenthes spices extracts in a suitably buffered mixture of $100 \mathrm{mM}$ Tris-HCL (pH 7.8) at ambient temperature. Wave length of $410 \mathrm{~nm}$, using extinction 
coefficient of $17000 \mathrm{M}^{-1} \cdot \mathrm{cm}^{-1}$ for the product formed (Wheelock, Severson et al. 2001, Gilham and Lehner 2005) Cecil 2021 UV/Vis spectrophotometer (Lab Equipment, England) set in a kinetics mode was used to measure the absorbance.

Enzyme activity $(U / L)=[(d A / d t) / \varepsilon . D f] .60$

Where $d A / d t=$ rate of absorbance change, $D f=$ dilution factor, $\varepsilon=$ extinction coefficient of lignin, $\mathrm{U} / \mathrm{L}=\mu \mathrm{mol}$ substrate converted per minute per litre.

\section{DISCUSSION}

Enzymes fractionation is a separation technique that is used to disassociate a mixture such as gas, solid, liquid, enzymes, suspension etc. into smaller fractions in which the composition varies in weight or gradient. Tangential flow filtration (TFF) is a speedy and effective technique for separation and purification of enzymes. This is done by basically connecting the TFF device to a pump and pressure gauge(s) with tubing and fittings. The process is easy, faster and above all, its accomplish greater concentrations in less time as compare to techniques such as dialysis, centrifugal devices or stirred cells (Schwartz and Seeley 2002).

These enzymes both from plants exudates and plants fluids contribute greatly to the breaking down of holocellulolysis.

The major enzymes accountable for the degradation of the crystalline structure of cellulose have been identified to be Endo-glucanase (EGs) which attacks the 1,4- $\beta$-glucosidic bonds and Exo-glucanase (CBHs), its attacks the non-reducible ends of crystalline structure of cellulose while hemicellulose (xylan) which is even more complex is degraded by multiple enzymes which include, Endo-xylanase for the hydrolyses of xylan and $\beta$-xylan esterase attacks xylooligosaccharides into xylose.

\section{CONCLUSION}

Different plant exudates from different parts of plants include enzyme cocktails used in prey traps, have been identified as a source of several useful enzymes which can be exploited for the lignin decomposition (delignification) and cellulose including hemicellulose decomposition (holocellulolysis); albeit, under limited conditions thus the concept of semi-deligni-holocellulolysis.

\section{ACKNOWLEDGMENT}

This research was sponsored by the National Research Foundation of South Africa, the CPUT's Vice Chancellors Prestigious Award (2019 to 2021) and University Research Fund RK16.

\section{REFERENCES}

[1] Angadam, J. O., et al. (2019). "Sustainable Nepenthes mirabilis Facilitated Recovery of Reducing Sugars from Grape Pomace." BioResources 14(2): 3944-3960.

[2] Baetz, U. and E. Martinoia (2014). "Root exudates: the hidden part of plant defense." Trends in Plant Science 19(2): 90-98. https://doi.org/10.1016/j.tplants.2013.11.006

[3] Chan, X.-Y., et al. (2016). "Microbiome and biocatalytic bacteria in monkey cup (Nepenthes pitcher) digestive fluid." Scientific reports 6: 20016.

https://doi.org/10.1038/srep20016
[4] Dlangamandla, N., et al. (2019). "Kinetic Parameters of Saccharomyces cerevisiae Alcohols Production Using Nepenthes mirabilis Pod Digestive Fluids-Mixed Agro-Waste Hydrolysates." Fermentation 5(1): 10. https://doi.org/10.3390/fermentation5010010

[5] Dlangamandla, N., et al. (2019). "Integrated Hydrolysis of Mixed Agro-Waste for a Second Generation Biorefinery Using Nepenthes mirabilis Pod Digestive Fluids." Processes 7(2): 64. https://doi.org/10.3390/pr7020064

[6] Flores, J. S. and R. V. Ricalde (1996). "The secretions and exudates of plants used in Mayan traditional medicine." Journal of herbs, spices \& medicinal plants 4(1): 53-59. https://doi.org/10.1300/J044v04n01_07

[7] Gallie, D. R. and S.-C. Chang (1997). "Signal transduction in the carnivorous plant Sarracenia purpurea (Regulation of secretory hydrolase expression during development and in response to resources)." Plant Physiology 115(4): 1461-1471. https://doi.org/10.1104/pp.115.4.1461

[8] Gilham, D. and R. Lehner (2005). "Techniques to measure lipase and esterase activity in vitro." Methods 36(2): 139-147.

https://doi.org/10.1016/j.ymeth.2004.11.003

[9] Lee, L., et al. (2016). "Carnivorous nutrition in pitcher plants (Nepenthes spp.) via an unusual complement of endogenous enzymes." Journal of proteome research 15(9): 3108-3117.

https://doi.org/10.1021/acs.jproteome.6b00224

[10] Manavalan, T., et al. (2017). "Optimization of acetyl xylan esterase gene expression in Trichoderma reesei and its application to improve the saccharification efficiency on different biomasses." Process Biochemistry 58: $160-166$. https://doi.org/10.1016/j.procbio.2017.04.042

[11] Mirhosseini, H. and B. T. Amid (2012). "A review study on chemical composition and molecular structure of newly plant gum exudates and seed gums." Food Research International 46(1): 387-398. https://doi.org/10.1016/j.foodres.2011.11.017

[12] Mithöfer, A. (2011). "Carnivorous Pitcher Plants: Insights in an Old Topic." Phytochemistry 72(13): 1678-1682. https://doi.org/10.1016/j.phytochem.2010.11.024

[13] Okwu, D. and F. U. Nnamdi (2008). "Evaluation of the chemical composition of Dacryodes edulis and Raphia hookeri Mann and Wendl exudates used in herbal medicine in south eastern Nigeria." African Journal of Traditional, Complementary and Alternative Medicines 5(2): 194-200. https://doi.org/10.4314/ajtcam.v5i2.31273

[14] Pichersky, E. and R. A. Raguso (2018). "Why do plants produce so many terpenoid compounds?" New Phytologist 220(3): 692-702. https://doi.org/10.1111/nph.14178

[15] Puri, B. and A. Hall (1998). Phytochemical dictionary: a handbook of bioactive compounds from plants, CRC press.

[16] Schulze, W. X., et al. (2012). "The protein composition of the digestive fluid from the venus flytrap sheds light on prey digestion mechanisms." Molecular \& Cellular Proteomics 11(11): 1306-1319. https://doi.org/10.1074/mcp.M112.021006

[17] Schwartz, L. and K. Seeley (2002). "Introduction to tangential flow filtration for laboratory and process development applications." Pall Scientific \& Technical Report, PN 33213.

[18] Takeuchi, Y., et al. (2015). "Bacterial diversity and composition in the fluid of pitcher plants of the genus Nepenthes." Systematic and applied microbiology 38(5): 330-339. https://doi.org/10.1016/j.syapm.2015.05.006

[19] Wen, F., et al. (2007). "Extracellular proteins in pea root tip and border cell exudates." Plant Physiology 143(2): 773-783. https://doi.org/10.1104/pp.106.091637

[20] Wheelock, C. E., et al. (2001). "Synthesis of new carboxylesterase inhibitors and evaluation of potency and water solubility." Chemical research in toxicology 14(12): 1563-1572. https://doi.org/10.1021/tx015508+

[21] Zabed, H., et al. (2016). "Fuel ethanol production from lignocellulosic biomass: an overview on feedstocks and technological approaches." Renewable and Sustainable Energy Reviews 66: 751-774. https://doi.org/10.1016/j.rser.2016.08.038 


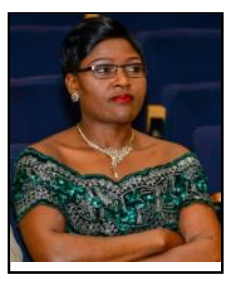

J.O. Angadam was born in Akutah Andek Cameroon in 1989, obtaining a Master of Environmental Health

summa cum laude in 2019, Baccalaureus

Technologiae in Biomedical Technology

(Biotechnology) in 2016, and a National Diploma in

Biotechnology in 2015, at the Cape Peninsula

University of Technology, Cape Town, South Africa.

She obtained her Advanced Level Certificate in

Natural Sciences (Matric) in 2007 in Cameroon at the

Protestant College Bali, Bali Cameroon with her First School Leaving Certificate (2000) being obtained from the Presbyterian School Andek Cameroon. Currently, she performs duties as an office co-ordinator for BioERG, Teaching Assistant for the Department of Biotechnology and Consumer Sciences, while being an assistant laboratory technician, and tutor. Ms Angadam, has published in Thompson Reuters listed international Journals. 